\title{
PERSPECTIVE
}

\section{Risk factors for intraocular melanoma and occupational exposure}

\author{
Jean-Michel Lutz, Ian A Cree, Alex J Foss
}

Ocular melanoma is an uncommon cancer. Age standardised incidence ranges from 0.4 to 1.2 cases per 100000 within Europe and from 0.1 to 2.3 worldwide (figures from WHO and International Agency for Research on Cancer (IARC)). Only one report ${ }^{1}$ suggests any change over decades. ${ }^{2-6}$ However, incidence data from the USA show a decrease over the period 1973-89.

The behaviour of intraocular melanoma varies with site. Tumours located in the iris form $10 \%$ of eye melanomas ${ }^{8}$ and usually have low grade histology with a good prognosis. ${ }^{9}$ Local excision is effective in most such cases although some may require enucleation, and metastasis is seen in only $3 \%$ of cases. In contrast, melanoma of choroid or ciliary body has a poor prognosis, although late metastasis after removal of the primary tumour is common. Metastasis is haematogenous and 1 year survival after liver metastasis not higher than $10 \%{ }^{10}$ Raivio $^{8}$ in Finland observed that survival rates at 5,10 , and 15 years were $65 \%, 52 \%$, and $46 \%$ respectively. Among the $12 \%$ of patients surviving at least 20 years, $21 \%$ developed metastasis thereafter. Treatment of metastatic disease by chemotherapy has been disappointing with less than $1 \%$ response rates to systemic DTIC based chemotherapy. ${ }^{11}$ Prognosis therefore reflects the development of metastasis uninfluenced by treatment, although recent developments hold some hope of progress. ${ }^{1213}$

Twenty years ago "many of the difficulties in diagnosing choroidal melanomas which clinicians confronted in the past [had] been eliminated". ${ }^{14}{ }^{15}$ The past two decades have seen advances in classification, now widely accepted, ${ }^{16}$ and continuing refinement of prognostic factors influencing outcome in these patients. ${ }^{1-20}$ However, despite a number of studies of risk factors for intraocular melanomagenesis, the cause of this tumour is far from clear.

During the 1980s, with increased interest in epidemiology generated by higher frequency of skin melanoma, additional and more detailed investigations were conducted either by reviewing groups of patients ${ }^{21-23}$ or by conducting specifically designed case-control studies, ${ }^{24-29}$ allowing these groups to test hypotheses related to exposure to various environmental factors. Most of the publications during this period show a positive association with pre-existing naevi or melanocytosis, light eye, hair, and skin complexion and a null or weak association with hormonal factors and earlier malignancy. In 1986 a large clinical trial, the Collaborative Ocular Melanoma Study, ${ }^{30}{ }^{31}$ started in the United States and Canada, including patients until 1994. This large scale study has been designed to provide important information regarding the choice of treatment, as well as natural history, quality of life, and pathology findings. ${ }^{32}$

\section{Potential risk factors}

A familial history of uveal melanoma $\mathrm{a}^{33-43}$ and pre-existing naevi ${ }^{4-48}$ have been postulated as predisposing factors. A large range of risk factors have been investigated (for example, sex related factors, ${ }^{27}{ }^{29} 49-51$ social class, and socioeconomic factors, ${ }^{18}{ }^{52-54}$ lightness of complexion and hair, ${ }^{53}$ eye colour, ${ }^{232455}$ sunlight exposure, ${ }^{2556-59}$ smoking, ${ }^{60}$ viruses, ${ }^{61}{ }^{62}$ chemicals, ${ }^{63}$ links with other cancers ${ }^{28}{ }^{64-69}$ ), but no causative agent has been recognised.

Following advances in understanding of the pathogenesis of skin melanoma, ${ }^{70}$ several studies investigated the role of ultraviolet light, ${ }^{56}{ }^{58}$ finding a positive association (relative risk (RR) significantly higher than 3). However, these results remain controversial ${ }^{53}{ }^{71-73}$ and the recent drop in incidence in the United States is further evidence that this is not a major factor. ${ }^{7}$ Furthermore, dosimetry studies suggest that only $1-2 \%$ of incident radiation in the ultraviolet $B$ range reaches the back of the eye. ${ }^{74}$

Several studies have addressed the possible importance of genetic factors, following the demonstration of genetically determined predisposition in other cancers. ${ }^{75-86}$ Clear evidence of a genetic component in uveal melanoma is the unbalanced racial risk with a strong predominance among white people and an absence among dark skinned people. ${ }^{787}$ There is a clear racial predisposition which follows the same pattern as cutaneous melanoma. Familial predisposition has been known to occur since 1892 following Silcok's report of uveal melanoma in three successive generations. However, such families are rare and although many familial reports have been published since then, it is clear that genetic factors are only part of the aetiological process. A specific genetic alteration, if any, would probably only explain a small proportion of disease, as has been shown for BRCA1 and BRCA2 in breast cancer. Currently, the data therefore suggest that environmental risk factors do exist, but that these are yet to be demonstrated.

\section{Occupational exposure and eye melanoma: investigation of potential risk factors} Most environmental risk factors can be investigated by occupational exposure analysis, but the rarity of uveal melanoma has prevented many studies of this subject. However, there is some evidence that this may be important. Albert et $a l^{63}$ reported a significant excess of choroidal melanoma among the white workers in a chemical industry in West Virginia. However, this observation is incidental, as the point of interest was the incidence of disease rather than a search for aetiological factors. Since then, various chemicals have been reported to induce ocular melanocytic tumours in animals, ${ }^{98}$ including nickel, platinum, radium, and some other compounds. 
Table 1 Relative risk estimates for measuring the association between eye melanoma and industries according to the industry classification system (from Ajani et $a l^{\circ}$ )

\begin{tabular}{|c|c|c|c|}
\hline \multicolumn{2}{|l|}{ Occupation exposure cross linkage system (OEC) } & \multicolumn{2}{|c|}{ Bureau of census classification system (BOC) } \\
\hline Agriculture, forestry, fishing & 2.02 & 1.52 & Agriculture, forestry, and fisheries \\
\hline Construction & 0.49 & $\begin{array}{l}0.53 \\
1.18\end{array}$ & $\begin{array}{l}\text { Construction } \\
\text { Manufacturing }\end{array}$ \\
\hline Paper and wood & 1.04 & & \\
\hline Glass, clay, and stone & 1.32 & & \\
\hline Metal & 4.42 & & \\
\hline Machinery & $0.33^{\star}$ & & \\
\hline \multirow[t]{6}{*}{ Transportation methods, ship building, aircraft } & 0.67 & 1.23 & Transportation, communications, and other public utilities \\
\hline & & 1.08 & Wholesale trade \\
\hline & & 1.21 & Retail trade \\
\hline & & 0.60 & Finance, insurance, and real estate \\
\hline & & 0.88 & Business and repair services \\
\hline & & 0.71 & Personal services \\
\hline Food and tobacco & 1.33 & & \\
\hline Textile & 0.77 & & \\
\hline Chemicals, drugs, and paints & 0.24 & & \\
\hline Rubber, plastic, and synthetics & 0.50 & & \\
\hline Leather & 3.06 & & \\
\hline Medicine and science & 0.73 & & \\
\hline \multirow[t]{3}{*}{ Entertainment and recreation } & 0.82 & 3.02 & Entertainment and recreation services \\
\hline & & 0.55 & Professional and related services \\
\hline & & 1.06 & Public administration \\
\hline Art & 1.03 & & \\
\hline & & 1.61 & Others \\
\hline Other occupations with few chemical exposures & 1.35 & & \\
\hline
\end{tabular}

^Significant at $\mathrm{p}<0.05$.

Several occupational clues to aetiology appeared when Swerdlow, ${ }^{1}$ using the UK Registrar General classification with 26 occupation orders, reported a significant excess of proportional registration ratio in three categories: electrical and electronic workers, administrators and managers, and technical workers and artists. Results from a subsequent Canadian study conducted between 1979 and 1981 with 65 eye melanoma cases and their age and sex matched controls were published by Gallagher et $a l^{4}$ As well as host factors, sun exposure variables and medical factors, occupation and chemical exposure were investigated, using a detailed occupational history. No individual occupation appeared to be at significantly elevated risk, but when grouped, a predominantly indoor managerial group ("government workers") had an odds ratio $(\mathrm{OR})$ of $3.5(\mathrm{p}=0.006)$ after controlling for hair and eye colour. No indication of elevated risk was found for other occupational groups, including chemical, electrical, or electronic workers.

In 1990, Vagero et $a l^{89}$ using cancer registration data in England and Wales analysed the occupation of 662 patients with ocular melanoma, using an age adjusted proportional registration ratio (PRR, a comparison of the proportion of all cancers which melanomas constitute in a particular occupation with the corresponding proportion in all occupational groups combined, adjusted for age). Information about occupation was coded according to the 1970 OPCS (Office of Population Censuses and Survey) classification system. Only significant results are noted here: for men, an excess incidence was found in clerical workers, PRR $=1.4$ (95\% CI 1.0-1.8), in accordance with Gallagher's report. ${ }^{24}$ Top rank occupations with highest PRR were among male athlete sportsmen (a priori not known for indoor activities) and electrical engineers, and among female commercial travellers and kitchen hands. If occupations for men and women were combined, scientists $(\mathrm{PRR}=2.2, \mathrm{NS})$, judges $(\mathrm{PRR}=1.9, \mathrm{NS})$, and teachers ( $P R R=1.8,95 \%$ CI 1.2-2.5) had the highest risk.

Ajani et $a l^{90}$ specifically designed an occupational population based case-control study with 197 cases and twice as many controls. They interviewed the subjects, including questions on constitutional factors, ocular and medical histories, ultraviolet exposure, occupational history and exposure related to work occurring 15 years before the interview. They used two different occupation exposure matrices: the occupation exposure cross linkage system
(OEC) (16 categories for industries, nine categories for occupations) and the Bureau of Census classification system (BOC) (13 categories for industries, six categories for occupations). OEC links suspect carcinogens to industry and occupation, ${ }^{91}$ which then are used to deduce the agents to which a subject might have been exposed occupationally and to group subjects whose occupational history suggests exposure to a particular agent. This system was used to categorise different exposures into three level groups of exposure. Results from this specific exposure coding found no positive association between any group of exposure and eye melanoma, with two groups (alkylating agents and other organic compounds, NOS), apparently having a significant negative impact on incidence. At the third level (specific agent of exposure) only one product (alicyclic halogens) within the organic compounds group was positively associated with ocular melanoma but this result was not significant (OR 1.95 (95\% CI 0.84-4.53)).

\section{Future risk assessment in uveal melanoma}

Study design, selection bias, and occupation coding appear to be the three main issues when looking at risk factors for occupational exposure. The choice of study design is always a balance between several contradictory arguments. The ideal, a cohort study among exposed workers (for example, farmers or fishermen), would not be feasible because of the low incidence of this disease. Although wide open to criticism, case-control studies do provide valid OR estimates and present some advantages. Firstly, the cases consist only of the disease of interest (here uveal melanoma), particularly if a standard pathological review is conducted for all eligible cases, and a clear position is adopted for non-histologically confirmed melanoma. Secondly, data may come either from hospital or population based registries and there is no necessity to be exhaustive. However, a limitation of a case-control study is that the number of occupational exposure categories can be greater than the number of cases! The sample size has therefore to be large enough to obtain sufficient numbers in all categories.

Classically, the major limitation of a case-control study is selection bias, usually when selecting controls. Cases and controls must be unbiased with respect to age which is obviously linked with the duration of occupation, whatever 
the technical possibilities of statistical adjustment. For a true aetiological factor, cases are expected to be more exposed than the controls, but this may be difficult to verify in some situations. If we assume a dose-response effect, eye melanoma among young cases should be associated either with a strong association with environmental exposure, if any, or with a personal risk factor, or both. The current absence of clear answers from previous studies tells us that there is unlikely to be a strong association with any occupational exposure. Young cases, with a presumed shorter exposure might have other (unknown) aetiological or confounding risk factors, when young controls would not have those personal factors. Even with controls matched for age, selection of an unbalanced number of young cases would therefore lead to an overestimate the role of occupational exposure. With data originating from tumour registries, this issue should not be a problem, since it is (theoretically) possible to check the completeness of registration and therefore to compare the age distribution of included cases with the population age distribution of cases. If data come from referral centres, it is important to verify that there is no bias towards referral of younger cases, as others could be treated locally, either because they are more easily diagnosed and treated by simple enucleation, or because they have a poorer prognosis. For both sources of data, it is worth checking the age distribution of cases.

Ajani's study ${ }^{90}$ dealt conclusively with the key issue of occupation coding effect. Comparison of the findings drawn from both systems (Table 1) shows some consistency, supporting both positive (agriculture) and negative (construction) associations. However, the differences present between studies (transportation services, entertainment, and arts) make interpretation difficult and may be related to misclassification of occupational exposure or to variations in the coding systems used.

In addition to coding system problems, the case-control design introduces one other potential source of error. Comparisons are made for groups exposed versus not exposed to a particular occupation at a particular time. Even if one assumes perfect occupation exposure coding, the presence of any agent in the reference group (that is, combining all other exposures) with a similar effect might dilute the effect of the exposure of interest. Ideally, samples should be divided into three groups: occupations certainly exposed, those certainly not exposed, and the occupations exposed to agents with similar or unknown effect. Comparisons could then be made between the exposed and non-exposed groups. However, statistical constraints of study power and occupation coding uncertainties generally do not allow the creation of such categories.

\section{Conclusion}

It is clear from this overview of occupational risk factors for uveal melanoma that there are potential link and areas for future studies of exposure can be seen. The role of ultraviolet irradiation remains controversial. The possibility that other forms of radiation and exposure to DNA damaging agents might be important is clearly worth consideration.

J-M LUTZ

Registre Genevois des Tumeurs, 55 Bvd de la Cluse, CH-1205 Genève, Switzerland

I A CREE

Department of Pathology, Institute of Ophthalmology, University of London, Bath Street, London EC1V 9EL

A J FOSS

Department of Ophthalmology, Queen's Medical Centre, Nottingham NG7 2UH

Correspondence to: Dr Lutz.
1 Swerdlow AJ. Epidemiology of eye cancer in adults in England and Wales, 1962- 1977. Am ₹ Epidemiol 1983;118:294-300.

2 Keller AZ. Histology, survivorship and related factors in the epidemiology of eye cancers. Am F Epidemiol 1973;97:386-93.

3 Strickland D, Lee JA. Melanomas of eye: stability of rates. Am $\mathcal{F}$ Epidemiol 1981;113:700-2.

Osterlind A. Trends in incidence of ocular malignant melanoma in Denmark 1943-1982. Int F Cancer 1987;40:161-4.

5 Egan KM, Seddon JM, Glynn RJ, et al. Epidemiologic aspects of uveal melanoma. Surv Ophthalmol 1988;32:239-51.

6 Mahoney MC, Burnett WS, Majerovics A, et al. The epidemiology of ophthalmic malignancies in New York State. Ophthalmology 1990;97:1143-7.

7 Foss AJ, Dolin PJ. Trends in eye cancer mortality among adults in the USA and England and Wales. Br f Cancer 1996;74:1687-9.

8 Raivio I. Uveal melanoma in Finland. An epidemiological, clinical, histological and prognostic study. Acta Ophthalmol (Suppl) 1977:1-64.

9 Sahel JA, Earle JD, Albert DM. Intraocular melanomas. In: DeVita VT Jr, Hellman S, Rosenberg SA, eds.Cancer: principles and practice of oncology. 4th ed. Philadelphia: JB Lippincott, 1993:1662-78.

10 Gragoudas ES, Egan KM, Seddon JM, et al. Survival of patients with metastases from uveal melanoma. Ophthalmology 1991;98:383-91.

11 Bedikian AY, Legha SS, Mavligit G, et al. Treatment of uveal melanoma metastatic to the liver: a review of the MD Anderson Cancer Center experience and prognostic factors. Cancer 1995;76:1665-70.

12 Leyvraz S, Spataro V, Bauer J, et al. Treatment of ocular melanoma metastatic to the liver by hepatic arterial chemotherapy. F Clin Oncol 1997; 15:2589-95.

13 Neale MH, Myatt N, Cree IA, et al. Combination chemotherapy for choroidal melanoma: ex vivo sensitivity to treosulfan with gemcitabine or cytosine arabinoside. Br F Cancer 1999;79:1487-93.

14 Zimmerman LE. Problems in the diagnosis of malignant melanomas of the choroid and ciliary body. The 1972 Arthur J Bedell Lecture. Am f Ophthalmol 1973;75:917-29.

15 Shields JA. Modern methods in the diagnosis of uveal melanomas. Trans Ophthalmol Soc UK 1977;97:407-11.

16 Gamel JW, McLean IW. Quantitative analysis of the Callender classification of uveal melanoma cells. Arch Ophthalmol 1977;95:686-91.

17 Foss AJ, Alexander RA, Jefferies LW, et al. Microvessel count predicts survival in uveal melanoma. Cancer Res 1996;56:2900-3.

18 Gamel JW, McLean IW, Foster WD, et al. Uveal melanomas: correlation of cytologic features with prognosis. Cancer 1978;41:1897-901

19 Zimmerman LE, McLean IW, Foster WD. Does enucleation of the eye containing a malignant melanoma prevent or accelerate the dissemination of tumour cells. Brf Ophthalmol 1978;62:420-5.

20 Gundersen T, Smith TR, Zakov N, et al. Choroidal melanocytic tumor observed for 41 years before enucleation. Arch Ophthalmol 1978;96:208992.

21 Velazquez N, Jones IS. Ocular and oculodermal melanocytosis associated with uveal melanoma. Ophthalmology 1983;90:1472-6.

22 Gonder JR, Shields JA, Albert DM, et al. Uveal malignant melanoma associated with ocular and oculodermal melanocytosis. Ophthalmology 1982;89. 953-60.

23 Rootman J, Gallagher RP. Color as a risk factor in iris melanoma. Am $\mathcal{F}$ Ophthalmol 1984;98:558-61.

24 Gallagher RP, Elwood JM, Rootman J, et al. Risk factors for ocular melanoma: Western Canada Melanoma Study. $\mathcal{F}$ Natl Cancer Inst 1985;74: $775-8$.

25 Tucker MA, Shields JA, Hartge P, et al. Sunlight exposure as risk factor for intraocular malignant melanoma. N Engl f Med 1985;313:789-92.

26 Nordlund JJ, Kirkwood J, Forget BM, et al. Demographic study of clinically atypical (dysplastic) nevi in patients with melanoma and comparison subjects. Cancer Res 1985;45:1855-61.

27 Hartge P, Tucker MA, Shields JA, et al. Case-control study of female hormones and eye melanoma. Cancer Res 1989;49:4622-5.

28 Lischko AM, Seddon JM, Gragoudas ES, et al. Evaluation of prior primary malignancy as a determinant of uveal melanoma. A case-control study [see comments]. Ophthalmology 1989;96:1716-21.

29 Holly EA, Aston DA, Ahn DK, et al. Uveal melanoma, hormonal and reproductive factors in women. Cancer Res 1991;51:1370-2.

30 Albert DM. The ocular melanoma story. LIII Edward Jackson Memorial Lecture: Part II. Am f Ophthalmol 1997;123:729-41.

31 COMS. The Collaborative Ocular Melanoma Study (COMS) randomized trial of pre-enucleation radiation of large choroidal melanoma I: characteristics of patients enrolled and not enrolled. COMS report no 9 [see comments]. Am f Ophthalmol 1998;125:767-78.

32 COMS. Histopathologic characteristics of uveal melanomas in eyes enucleated from the Collaborative Ocular Melanoma Study. COMS report no 6 [see comments]. Am $\mathcal{F}$ Ophthalmol 1998;125:745-66.

33 Greer CH. Congenital melanoma of the anterior uvea. Arch Ophthalmol 1966;76:77-8.

34 Lynch HT, Anderson DE, Krush AJ. Heredity and intraocular malignant melanoma. Study of two families and review of forty-five cases. Cancer 1968;21:11-25

35 Lynch HT, Krush AJ. Heredity and malignant melanoma:implications for early cancer detection. Can Med Assoc F 1968;99:17-21.

36 Green GJ, Hong WK, Everett JR, et al. Familial intraocular malignant melanoma: a case report. Cancer 1978;41:2481-3.

37 Walker JP, Weiter JJ, Albert DM, et al. Uveal malignant melanoma in three generations of the same family. Am f Ophthalmol 1979;88:723-6.

38 Greene MH, Sanders RJ, Chu FC, et al. The familial occurrence of cutaneous melanoma, intraocular melanoma, and the dysplastic nevus syndrome. Am $\mathcal{F}$ Ophthalmol 1983;96:238-45.

9 Simons KB, Hale LM, Morrison HM Jr, et al. Choroidal malignant melanoma in siblings. Am f Ophthalmol 1983;96:675-80.

40 Canning CR, Hungerford J. Familial uveal melanoma. $\mathrm{Br} f$ Ophthalmol 1988;72:241-3.

41 Broadway D, Lang S, Harper J, et al. Congenital malignant melanoma of the eye. Cancer 1991;67:2642-52.

42 Young LH, Egan KM, Walsh SM, et al. Familial uveal melanoma. Am $\mathcal{f}$ Ophthalmol 1994;117:516-20.

43 Bercher L, Munier F, Zografos L, et al. Familial uveal melanoma. Klin Monatsbl Augenheilkd 1995;206:384-7. 
44 Yanoff M, Zimmerman LE. Histogenesis of malignant melanomas of the uvea. II. Relationship of uveal nevi to malignant melanomas. Cancer 1967; 20:493-507.

45 Ganley JP, Comstock GW. Benign nevi and malignant melanomas of the choroid. Am 7 Ophthalmol 1973;76:1-25

46 Vink J, Crijns MB, Mooy CM, et al. Ocular melanoma in families with dysplastic nevus syndrome. F Am Acad Dermatol 1990;23:858-62.

47 Van Hees CL, de Boer A, Jager MJ, et al. Are atypical nevi a risk factor for uveal melanoma? A case- control study. F Invest Dermatol 1994;103:202-5.

48 Bataille V, Sasieni P, Cuzick J, et al. Risk of ocular melanoma in relation to cutaneous and iris naevi. Int $\mathcal{F}$ Cancer 1995;60:622-6.

49 Lee JA, Storer BE. Malignant melanoma female/male death ratios letter. Lancet 1981;1:14.

50 Reintgen DS, McCarty KS Jr, Vollmer R, et al. Malignant melanoma and pregnancy. Cancer 1985;55:1340-4.

51 Egan KM, Walsh SM, Seddon JM, et al. An evaluation of the influence of reproductive factors on the risk of metastases from uveal melanoma. Ophthalmology 1993;100:1160-5.

52 Cooke KR, Skegg DC, Fraser J. Socio-economic status, indoor and outdoor work, and malignant melanoma. Int $\mathcal{F}$ Cancer 1984;34:57-62.

53 Graham S, Marshall J, Haughey B, et al. An inquiry into the epidemiology of melanoma. Am f Epidemiol 1985;122:606.

54 Tucker MA, Hartge P, Shields JA. Epidemiology of intraocular melanoma. Recent results. Cancer Res 1986;102:159-65.

55 Lock-Andersen J, Wulf HC, Knudstorp ND. Interdependence of eye and hair colour, skin type and skin pigmentation in a Caucasian population. Acta Derm Venereol 1998;78:214-19.

56 Holly EA, Aston DA, Char DH, et al. Uveal melanoma in relation to ultraviolet light exposure and host factors. Cancer Res 1990;50:5773-7.

57 Schwartz SM, Weiss NS. Place of birth and incidence of ocular melanoma in the United States. Int $\mathcal{F}$ Cancer 1988;41:174-7 (published erratum appears in Int $\mathcal{F}$ Cancer 1988;41:779)

58 Seddon JM, Gragoudas ES, Glynn RJ, et al. Host factors, UV radiation, and risk of uveal melanoma. A case-control study. Arch Ophthalmol 1990;108: $1274-80$.

59 English DR, Armstrong BK, Kricker A, et al. Sunlight and cancer. Cancer Causes Control 1997;8:271-83.

60 Egan KM, Gragoudas ES, Seddon JM, et al. Smoking and the risk of early metastases from uveal melanoma. Ophthalmology 1992;99:537-41.

61 Albert DM. The association of viruses with uveal melanoma. Trans Am Ophthalmol Soc 1979;77:367-421.

62 Albert DM. The role of viruses in the development of ocular tumors. Ophthalmology 1980;87:12-25.

63 Albert DM, Puliafito CA, Fulton AB, et al. Increased incidence of choroidal malignant melanoma occurring in a single population of chemical workers. Am $\mathcal{F}$ Ophthalmol 1980;89:323-37.

64 Schoenberg BS, Christine BW. Malignant melanoma associated with breast cancer. South Med f 1980;73:1493-7.

65 Osterlind A, Olsen JH, Lynge E, et al. Second cancer following cutaneous melanoma and cancers of the brain, thyroid, connective tissue, bone, and eye in Denmark, 1943-80. Natl Cancer Inst Monogr 1985;68:361-88.

66 Tucker MA, Boice JD Jr, Hoffman DA. Second cancer following cutaneous melanoma and cancers of the brain, thyroid, connective tissue, bone, and eye in Connecticut, 1935-82. Natl Cancer Inst Monogr 1985;68:161-89.

67 Bataille V, Pinney E, Hungerford JL, et al. Five cases of coexistent primary ocular and cutaneous melanoma [see comments]. Arch Dermatol 1993;129: 8-201.

68 Swerdlow AJ, Storm HH, Sasieni PD. Risks of second primary malignancy in patients with cutaneous and ocular melanoma in Denmark, 1943-1989. Int $\mathcal{F}$ Cancer 1995;61:773-9.
69 Turner BJ, Siatkowski RM, Augsburger JJ, et al. Other cancers in uveal melanoma patients and their families. Am $\mathcal{F}$ Ophthalmol 1989;107:601-8

70 Beral V, Evans S, Shaw H, et al. Malignant melanoma and exposure to fluorescent lighting at work. Lancet 1982;2:290-3.

71 Dolin PJ, Foss AJ, Hungerford JL. Uveal melanoma: is solar ultraviolet radiation a risk factor? Ophthalmic Epidemiol 1994;1:27-30.

72 Dolin PJ, Johnson GJ. Solar ultraviolet radiation and ocular disease: a review of the epidemiological and experimental evidence. Ophthalmic Epidemiol 1994;1:155-64.

73 Schwartz LH, Ferrand R, Boelle PY, et al. Lack of correlation between the location of choroidal melanoma and ultraviolet-radiation dose distribution. Radiat Res 1997;147:451-6.

74 Rosen ES. Filtration of non-ionizing radiation by the ocular media. In: Cronley-Dixon J, Rosen ES, Marshall J, eds. Hazards of light: myths and realities on the eye and skin. Oxford: Pergamon Press, 1986:145.

75 Mukai S, Dryja TP. Loss of alleles at polymorphic loci on chromosome 2 in uveal melanoma. Cancer Genet Cytogenet 1986;22:45-53.

76 Martinetti M, Tafi A, De Paoli F, et al. Immunogenetic heterogeneity of uveal melanoma. Cancer Detect Prev 1988;12:145-8.

77 Jager MJ, Volker-Dieben HJ, de Wolff-Rouendaal D, et al. Possible relation between HLA and ABO type and prognosis of uveal melanoma. Doc Ophthalmol 1992;82:43-7.

78 Conlon MR, Albert DM. Uveal melanoma. Int Ophthalmol Clin 1993;33:6776.

79 Jay M, McCartney AC. Familial malignant melanoma of the uvea and p53: a Victorian detective story. Surv Ophthalmol 1993;37:457-62.

80 Gordon KB, Thompson CT, Char DH, et al. Comparative genomic hybridization in the detection of DNA copy number abnormalities in uveal melanoma. Cancer Res 1994;54:4764-8.

81 Neugut AI, Kizelnik-Freilich S, Ackerman C. Black-white differences in risk for cutaneous, ocular, and visceral melanomas. Am f Public Health 1994;84:1828-9.

82 Prescher G, Bornfeld N, Becher R. Two subclones in a case of uveal melanoma. Relevance of monosomy 3 and multiplication of chromosome 8q. Cancer Genet Cytogenet 1994;77:144-6.

83 Speicher MR, Prescher G, du Manoir S, et al. Chromosomal gains and losses in uveal melanomas detected by comparative genomic hybridization. Cancer Res 1994;54:3817-23.

84 Singh AD, Wang MX, Donoso LA, et al. Familial uveal melanoma, III. Is the occurrence of familial uveal melanoma coincidental? Arch Ophthalmol 1996;114:1101-4

85 Singh AD, Shields CL, De Potter P, et al. Familial uveal melanoma. Clinical observations on 56 patients [see comments]. Arch Ophthalmol 1996;114: 392-9.

86 Singh AD, Shields CL, Shields JA, et al. Bilateral primary uveal melanoma. Bad luck or bad genes? Ophthalmology 1996;103:256-62.

87 Miller B, Abrahams C, Cole GC, et al. Ocular malignant melanoma in South African blacks. Br f Ophthalmol 1981;65:720-2.

88 Albert DM, Shadduck JA, Lin HS. Animal models for the study of uveal melanomas. Int Ophthalmol Clin 1980;101:177-85.

89 Vagero D, Swerdlow AJ, Beral V. Occupation and malignant melanoma: a study based on cancer registration data in England and Wales and in Sweden. Br F Ind Med 1990;47:317-24.

90 Ajani UA, Seddon JM, Hsieh CC, et al. Occupation and risk of uveal melanoma. An exploratory study. Cancer 1992;70:2891-900.

91 Hsieh CC, Walker AM, Hoar SK. Grouping occupations according to carcinogenic potential: occupation clusters from an exposure linkage system. Am $\mathcal{F}$ Epidemiol 1983;117:575-89. 